\title{
Literature Review on the Solar Energy Potential for Botswana
}

\author{
Wilbert R. Mutoko, Senior Lecturer/Course Manager \\ School of Business and Leisure, \\ Botswana Accountancy College, Gaborone, Botswana \\ Phillis Mutoko, Strategy Consultant/ Motivational Speaker \\ Chief Cornerstone Holdings (Pty) Ltd, Gaborone, Botswana
}

\begin{abstract}
Renewable energy sources are easily accessible and clean to the environment. Solar energy is one of the best forms of renewable energy, particularly for a country such as Botswana. Paradoxically, Botswana finds herself importing electricity and experiencing power cuts, yet she has abundant sunshine almost all-year round that could be converted to electric power. This paper seeks to investigate through literature search, the potential for Botswana to convert her copious solar radiation into solar energy. A comparison of different forms of renewable energy are made. Particular attention is drawn to the case of Australia which has experience in use of solar energy and has a similar climate to that of Botswana. Findings from literature search reveal that Botswana stands a great chance of using solar power to improve the livelihood of its people and businesses. Recommendations to policy makers and the private sector are that there is urgent need to put in place policies, regulations and frameworks to support solar generation and reduce reliance on electricity importation and coal production which is not sustainable. The authors propose a conceptual model to help policy makers in implementing solar energy projects in Botswana.
\end{abstract}

Keywords: Solar Energy, Botswana, Australia, Renewable Energy

\subsection{Introduction}

In the past few years, there have been power outages in several African countries including countries such as South Africa and Botswana (Prasad, \& Samikannu, 2018). South Africa would not be expected to have power shortages because it is a major energy (electricity) producer and exporter. Botswana would not be anticipated to suffer power shortages because of the coal- powered Morupule B Power Plant, which project has delayed and failed 
(Jacobs, 2018; Streatfeild, 2018). Furthermore, Botswana has abundant availability of solar radiation that could be converted into solar power (BITC, 2016). Without enough electric power, the country's productivity declines industries operate below expectations, people lose jobs, and there are shortages of products on the market and inflation increases.

There is an acute shortage of literature on solar energy in Botswana. Therefore, the researchers had to rely mostly on international sources (databases), of which there are few peer-reviewed journal articles on the subject. This means that this study will possibly contribute to the body of knowledge on renewable sources of energy.

Apart from common non-renewable sources of energy such as hydroelectricity, renewable sources of energy are more cost-effective and meet the world's demand for clean energy (UNDP, 2012). Boidus (2014) wrote the article "How solar can power Botswana." In the article, the author mentioned that renewable energy sources include wind, gas, water and solar. Botswana, however, does not have abundant wind, gas or water. Rather, Botswana has copious solar radiation, available almost throughout the year.

According to BITC (2016), Botswana has limited exploitable energy resources. Furthermore, Botswana relies on electricity and petroleum products' importations. Available energy resources include solar, coal and bioenergy (biomass and biofuels) (UNDP, 2012). In the past year or so, however, South Africa, the main electricity supplier to Botswana has been experiencing serious power shortages resulting in electricity outages in Botswana (Mensah, 2018; Prasad, \& Samikannu, 2018). This has negatively affected production in domestic homes and industries alike.

Botswana has a warm climate which affords the nation abundant solar energy potentials (Vezzoli, Ceschin, Osanjo, M'Rithaa, Moalosi, Nakazibwe, \& Diehl, 2018). Unfortunately, the country is suffering the same power challenges as other countries that do not even have abundant sunshine that could potentially be turned into solar energy. Botswana is one of the most privileged countries in the world to use renewable energy because of the abundant solar radiation.

According to Boidus (2014), there are a few pilot solar projects that have been implemented in Botswana, such as the Phakalane project and the $20 \mathrm{kw}$ University of Botswana project in Mokolodi. However, Boidus (2014) argues that what Botswana needs is a commercial approach to provide energy to the demand of $700-800 \mathrm{MW}$ to the country. Authors of the current study posit that if Botswana takes a commercial approach to solar production, this could fast-track the national economic diversification drive (launched in 2010) and the economic stimulus program launched in 2016 (Vezzoli, et al., 2018).

The conclusions of Boidus (2014) are that Botswana should create a conducive environment by coming up with "policies, regulations, and 
framework that allows implementation of renewable energy and activities" and consider commercial projects "based on a business model to say "yes we are putting up a power station that will generate so much power and the enduser of that project is going to pay so much." While there have been discussions around solar energy generation at micro-level (AfDB, 2009), Botswana needs to consider major solar projects as has been done successfully in countries such as Australia and the United States of America.

This paper aims to review the literature and investigate the potential of Botswana generating solar energy at both individual home/industry level and commercial level to alleviate power shortages and support uninterrupted industrial development. Thus, the main objective is to make recommendations from the study, which are hoped to help policymakers and the private sector to convert the solar radiation opportunity into solar energy which can even be exported and increase national revenue. The study explores the following research questions: Question One, what is Botswana's current state of energy supply? Question two, what are Botswana's available energy sources? Question three, why is Botswana not taking advantage of the plenteous solar supply? Question four, what solutions can be put in place for Botswana to harness clean energy, particularly solar energy?

The rest of the paper is organized into a review of literature, methodology, results and discussion, conclusion, recommendations, acknowledgments, study limitations, and references.

\subsection{List of key words}

Solar energy - radiant heat and light from the sun that can be stored and harnessed in different ways for both current and future use.

Renewable energy - energy that comes from natural sources such as sunshine, rain, wind, waves and geothermal source.

Non-renewable energy - energy from sources that cannot be reused, for example, coal and firewood.

Sustainability - ability to meet today's needs without jeopardizing tomorrow's needs and environment.

Bioenergy - electricity and/or gas that is made from organic matter. This includes plants, timber, as well as agricultural and food waste, plus sewage.

Concentrating Solar Power (CSP) - technologies that use mirrors to reflect, concentrate and focus sunlight onto a specific point (Tlhalerwa \& Mulalu, 2019; (Maslamani, Omer, \& Majid, 2014)

\subsection{Review of Literature}

The literature review will look at the following research questions:

Q1 What is Botswana's current state of energy supply? 
Q2 What are Botswana's available energy sources?

Q3 Why is Botswana not taking advantage of the plenteous solar supply?

Q4 What solutions can be put in place for Botswana to harness clean energy, particularly solar energy?

\subsection{What is Botswana's current state of energy supply?}

According to Botswana Investors' Handbook (2014: 14), "Botswana's energy is mainly from coal-fired plants. Small diesel generators are used to power rural areas. The bulk of domestic electricity production is generated by the Morupule coal-fired station." This is a clear sign that Botswana currently relies on the limited coal energy which it augments with imported electricity from South Africa (Vezzoli, et al., 2018). Notably, Botswana does not have hydroelectric generation, as it is mostly desert land (84\% of Botswana's surface area of $581730 \mathrm{~km} 2$ ) (Botswana Investors' Handbook, 2014: 13) which does not have much water for pumping hydroelectricity. As a result, Botswana imports most electricity from ESKOM (South Africa) (Bloomberg, 2014; Ofetotse \& Essah, 2012).

If things had gone according to plan, Botswana's electricity problems would be over by now. Botswana started a power generation project called Morupule B. Power Plant, 2010/2011, which has not been successful. The AfDB (2009) reports that Botswana's Morupule B. Power Plant is situated next to the old Morupule Power Plant, about 280km north of Gaborone the capital city. The project was initiated by Botswana Power Corporation (financing part of the project) and the government of Botswana, with the financial help of the World Bank and African Development Bank (AfDB) (AfDB, 2009)). Unfortunately, the project did not go according to plan, resulting in the contractors failing to deliver. According to the Republic of Botswana (2014), with effect from the first of January 2014, a German company took over the maintenance and operation services of Morupule B Power Station from China National Electric Equipment Corporation (CNEEC) (SADOCC, 2014).

The project was expected to be completed by October 2012 with four units churning $150 \mathrm{MW}$ of electricity each. However, to date, only two units are in operation as the contractor faced delays and machine breakdowns (Bloomberg, 2014; the Republic of Botswana, 2014; Ofetotse \& Essah, 2012). Therefore, Botswana's electricity needs remain at bay. Thus, there is a need for an alternative energy source such as solar power.

\subsection{What is Botswana's available energy sources?}

Botswana has no known petroleum reserves. That leaves the country dependent on the following natural energy sources: coal, solar and bioenergy (UNDP, 2012; BITC, 2016: 33-34). The wind would have been another 
alternative energy source, but Botswana's wind speed is only limited to 2.0$3.5 \mathrm{~m} / \mathrm{s}$. Obviously, this level of wind speed is not enough for any viable windbased power generation project (Department of Energy, n.d.: 3). Natural gas has been discovered on the coal beds at Morupule Plant. While the gas could be a good source of energy, UNEP RISO Centre (2012) argues that the mining of natural gas has been very slow. This throws doubt at the possibility of natural gas being able to rescue Botswana from the current electricity shortages.

\subsubsection{Coal}

BITC (2016) suggests that Botswana has coal reserves of approximately 212 billion tones (Department of Energy, n.d.: 3; BITC, 2016: 33-34). UNEP RISO Centre (2012: 9) expresses it this way, "Botswana is also rich in coal reserves and coal has been mined at Morupule near Palapye since 1976 and estimated to amount to 212.8 billion tons." Morupule mine is the major deposit mine for Botswana's coal, supplying Morupule Power Station, BCL Smelter and Botswana Ash (BIDPA, 2012). There are other coal deposits in the country that are not yet exploited - Dukwe, Foley, Bobonong, Serule, Dutlwe, Ncojane, Letlhakeng, Mmamantswe, Mmamabula and Moijabana. This means that coal deposits could possibly be used for power generation in the long-term. Nevertheless, coal is not a clean form of energy as compared to solar energy. Furthermore, while coal deposits can get depleted, solar radiation is expected to last for as long as the earth is available. Thus, solar radiation is a better source of energy than coal.

\subsubsection{Bioenergy}

According to the Department of Energy (n.d. 3), Botswana has woody biomass loading that ranges from 3.6-4.3 tonnes per ha per annum of shrub savanna to 4.8-10.6 tonnes per ha per annum of dense forest. Bioenergy on its own in Botswana could meet $1 / 3$ of the country's national energy needs, especially for open-fire cooking; of which approximately $74 \%$ of rural population depends on (BITC, 2016: 33-34; Department of Energy (n.d.: 4).

While bioenergy includes food waste recycling, sewage recycling and biogas from manure; these forms of bioenergy are not rampant in Botswana (Pollmann, Podruzsik, \& van Rensburg, 2019). This is because the production of biogas requires large sums of capital and can be dangerous to members of the public (Pollmann et al., 2019; Salahuddin, Ali, Vink \& Gow, 2019). Thus, the main bioenergy source in Botswana is firewood.

\subsubsection{Solar}

According to Okonkwo \& Nwokoye (2014), solar energy is not evenly distributed across the globe. Some countries receive more sunshine than others 
depending on location and weather patterns (Tola, 2015). Botswana has one of the highest solar radiation levels in the world, with a mean annual solar insulation of 21MJ per square meter per day (Department of Energy, n.d.: 3). This high level of solar radiation automatically suggests that Botswana should be one of the foremost countries on solar energy production. Currently, Botswana is trying to generate power through the coal project, but as argued by Boidus (2014), if Botswana goes the route of solar, it will have many benefits for the nation, including no pollution and the fact that solar is renewable (BITRI, 2018; Prasad \& Samikannu, 2018).

Furthermore, the sun is the most plentiful energy source on the earth (Maslamani, Omer, \& Majid, 2014)

\subsection{Why is Botswana not taking advantage of the plenteous solar supply?}

Botswana has not taken advantage of the solar energy potential due to the lack of specific policy in solar energy. The earlier Botswana puts a policy framework in place, the better for the country in terms of energy supply (Tola, 2015).

2.4 What solutions can be put in place for Botswana to harness clean energy, particularly solar energy?

Among the possible solutions that Botswana can implement, the authors of this paper suggest a conceptual model.

\subsubsection{Conceptual Model}

The authors of this paper propose the following conceptual model to give an idea to policymakers and other stakeholders on how the planning and implementation of solar projects could be done in Botswana. The conceptual model is illustrated in Figure 1.

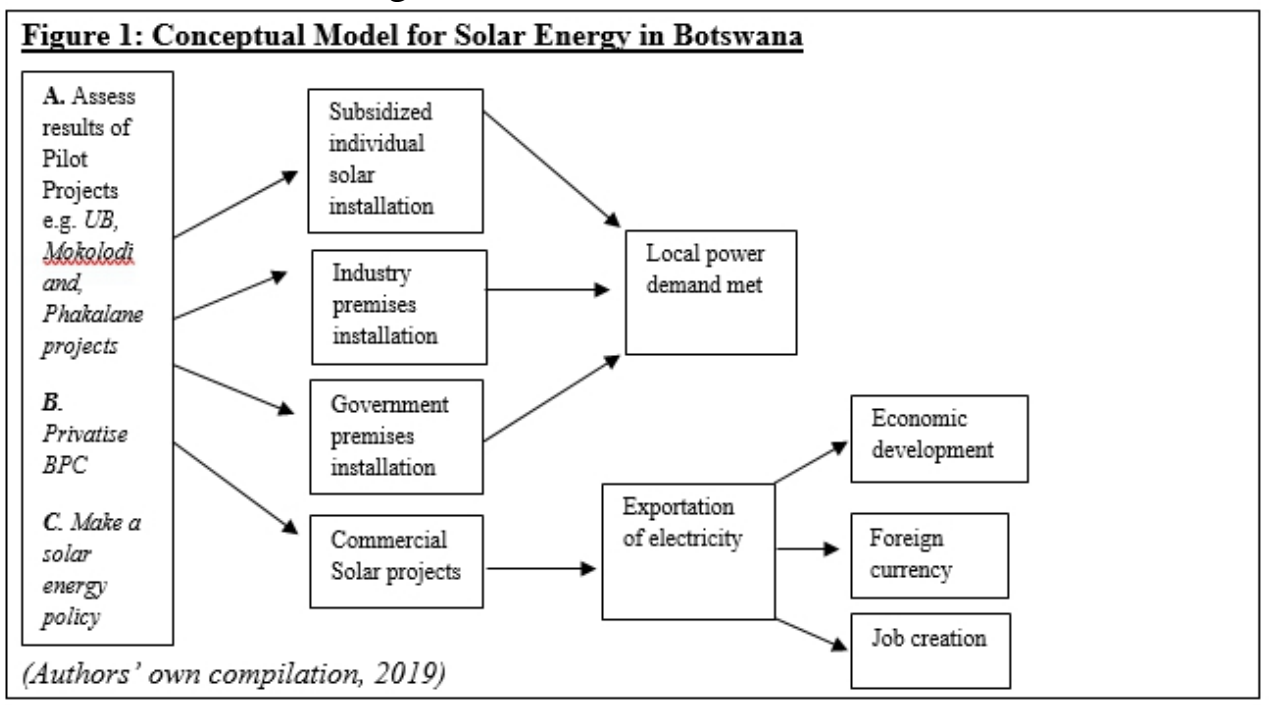


As shown in Figure 1, the conceptual model adopts some of its concepts from literature. According to literature, there are already a few pilot solar energy projects such as the University of Botswana - Mokolodi Solar Project and Phakalane Solar Project (Baek, Jung \& Kang, 2019). Authors of this current study suggest that a few more pilot projects are needed in Botswana to supplement current projects. After that, the country should privatise the Botswana Power Corporation (BPC) to ensure the efficient running of the giant corporation ahead of the solar energy projects. Then policymakers should come up with a solar energy policy that could possibly pursue four main solar generation avenues: 1) subsidized individual solar installation (whereby government subsidizes home solar installation. Families install solar panels on their roofs.); 2) industry premises installation (where industries are encouraged to install and use solar energy on their premises); 3) government premises installation (where government installs and uses solar power in their premises) and 4) commercial solar projects (whereby government and private sector come up with major solar power station(s) that generate power mainly for exportation).

The first three ways of solar generation in the conceptual model are hoped to meet local solar power demand; while commercial solar power station(s) aim at generating solar energy to supply some local entities, but mainly for exportation. Exportation will help create jobs, empower local entrepreneurs, earn foreign currency and increase gross domestic product.

\subsection{Methodology}

This paper aims to the review literature and investigate the potential of Botswana generating solar energy at both individual home/industry level and commercial level to alleviate power shortages and support uninterrupted industrial development. Botswana's consistent importation of electricity and recent frequent power cuts has been counter-productive to the country. Thus, power cuts have negatively affected productivity in both the private and public sectors. A literature search has been done to find out ideas on how other countries have implemented solar projects and how Botswana could harness its sunshine into solar energy. The literature search involved journal papers, databases, and government websites, among others. A conceptual model has been proposed by the authors of this paper to solve power challenges in Botswana.

While lessons have been drawn from other African countries on solar energy, attention has been put on Australia which shares a similar climate to Botswana.

Data was gathered from peer-reviewed journal articles, private and public sector reports, official country websites, books, conference papers, 
published and unpublished technical papers, official blogs, and other related sources.

However, the methodology of the research literature review adopted in this study is limited in that it lacks field study which could possibly give results on the ground. It only looks at studies that have already been published in the past (secondary data). Another limitation of the research literature review is that it considers various researches which had different research designs and approaches which may not be easy to compare in terms of specificity and coherence.

However, although the literature review has its weaknesses, the researchers take this literature study as a foundation for future studies.

\subsection{Results and Discussion}

This section looks at the results of the literature search. The results and discussion of findings are arranged following each research question.

\subsection{What is Botswana's current state of energy supply?}

Thalerwa \& Mulalu (2019) carried out an assessment of solar energy potential in Botswana, which concluded that Botswana has an enormous Concentrating Solar Power (CSP) potential that has the capability of exceeding the current peak energy demand by an order of magnitude. However, this is possible if the authorities come up with a policy framework that supports future investment in solar thermal power. The study suggested that the districts that have the highest CSP potential are the Central and Kgalagadi districts, with each having about 90GW each. Furthermore, the Southern District was deemed to have more land suitable for CSP.

Therefore, the success of solar projects depends on the country under consideration and its strengths (Islam, Huda, Abdullah, \& Saidur, 2018); Cavallaro, Zavadskas, Streimikiene, \& Mardani, 2019). Botswana's greatest strengths are that solar radiation is one of the highest in the world for almost all-year-round. Thus, solar energy solutions tailor-made for Botswana need to be implemented.

\subsection{What are Botswana's available energy sources? \\ 4.2.1 Coal}

Botswana has large deposits of coal that have sparsely been tapped. However, the question is, how sustainable is coal, which is a non-renewable energy source.

BIDPA (2012) wrote a paper to assess the opportunities and risks of coal mining. In their findings, they discovered that coal mining in Botswana is probably the largest coal reserve in Africa. But coal mining could be in jeopardy due to declining commodity prices and changing global settings 
regarding fossil fuels. Therefore, BIDPA (2012) recommended that the Botswana government should quickly construct a railway to the coast to carry the coal, development of the national water grid, and supporting industrial policy. Failure of this would mean that coal energy and coal export revenue would be lost. In 2016, it has become evident that none of the suggested plans of action by BIDPA (2012) was put in place, hence, with world falling prices of commodities; coal is not the hope for Botswana, but probably solar energy.

The authors of this current study, therefore, deduce that coal is a vast resource in Botswana, as indicated by the many coalfields in the country; coal's four major drawbacks compared to solar energy, that is, coal is (i) costly to mine compared to sunshine which just needs to be attracted; (ii) coal pollutes the environment while solar is green and safe for the environment; (iii) coal is heavy and thus, costly to transport compared to sunshine; and (iv) coal is non-renewable, that is its deposits can get depleted; whereas sunshine is almost eternal.

Due to the above-mentioned drawbacks of coal over solar, solar needs to be explored as an alternative power choice for Botswana.

\subsubsection{Bioenergy}

While bioenergy is a good source of energy, mostly in rural Botswana; the main question is how sustainable is bioenergy?

A study by Mphinyane, Akanyang, Mulale, Van Deventer, Magole, Perkins, \& Chanda (2018) explored the utilization of firewood and implication on trees in Mopipi Village in the Boteti-Sub District. The authors interviewed 79 households out of 383 households in the Mopipi Village. The study findings were that the firewood consumption rate per household per day stood at $10 \mathrm{~kg}$. Thus, at that rate of consumption, it is evident that bioenergy is not a sustainable energy source, as trees tend to reduce in size. This is furthermore complicated by the negatively changing weather patterns in Botswana, whereby rain is no longer dependable, hence vegetation and trees no longer get regular rains as in the past decades (Nkemelang \& Zaroug, 2018; Spear, Haimbili, Baudoin, Hegga, Zaroug, Okeyo, \& Angula, 2018).

While bio-energy is easily available especially among rural communities, it has four major drawbacks compared to solar energy which are that bio-energy is (i) an air pollutant as compared to sunshine which is green and safe to the environment (Tola, 2015); (ii) cutting of trees results in deforestation and land degradation which ultimately culminates in disturbances in the water cycle and natural ecosystem; (iii) wood is heavy and thus, costly to transport compared to sunshine; and (iv) wood is nonrenewable, that is trees can get depleted; whereas sunshine is almost eternal.

While bioenergy could help solve one-third of Botswana's energy demands, solar stands a better chance. Due to the above-mentioned drawbacks 
of bioenergy over solar, solar needs to be explored as an alternative power choice for Botswana.

\subsubsection{Solar}

World Bank (2012: 31, 47) sums up the need for Botswana to quickly compare available energy sources and act this way, "It is important for Botswana to not entirely rely on coal in the future as it has a high carbon footprint. The country further needs to develop the potential of renewable energy sources, solar power. Energy accounting could assist with predicting future electricity shortages, optimising energy use mixes and encouraging energy efficiency and fuller exploitation of under-utilized energy resources."

Among sources of energy for Botswana, solar keeps being repeated. Advantages and disadvantages of solar energy follow: the cleanness of solar energy, it is light and easily accessible. However, the disadvantages of solar energy are mainly that it can be expensive to gather equipment at first (AfDB, 2009).

A study by BITRI (2018) revealed that the presence of renewable energy can bring some immediate benefits to the Botswana power system, that is, saving on coal fuel and diesel fuel, saving on imports and arrest electricity interruptions, and the concomitant economic costs to electricity customers.

Furthermore, according to the Sunday Standard (2018) Botswana "receives 3,200 hours of sunshine per annum with average insolation on a horizontal surface of $21 \mathrm{MJ} / \mathrm{m} 2$. This is one of the highest rates of insulation in the world, according to Berman (Energy Expert).

Under the Masa 2020 strategy, BPC has embarked on a comprehensive renewable power development strategy, in which it will develop and operate a 100MW solar power plant in 2019. It also looks to develop and operate mini hybrid power plants in 20 isolated villages, a total of $30 \mathrm{MW}$ as a joint venture. The Corporation will further build 12 smaller solar PV plants in dedicated villages, a total of $75 \mathrm{mw}$ as IPPs."

The above assertions from Sunday Standard (2018) show an effort by $\mathrm{BPC}$, however, this is not enough solar energy output to supply the country and have extra energy to export. That is why this current paper suggests a conceptual model as shown next.

\subsection{Why is Botswana not taking advantage of the plenteous solar supply?}

Ofetotse \& Essah (2012) carried out a study to establish how Botswana could explore its energy concept. They employed a literature review, questionnaire survey, and empirical study. Findings showed an increased output from $100 \mathrm{MW}$ to $2595 \mathrm{MW}$ plus, thus assuming $85 \%$ plant capacity. They argued that while BPC and the government predicted positive assertions 
such as finishing the second phase of the Morupule B. Project by 2013, that was too ambitious. They suggested that predictions should be more realistic. Ofetotse \& Essah (2012)'s findings are like suggestions by BIDPA (2012) that Botswana should not just wish well on coal revenue, but rather systems and policies must be put in place urgently. What this helps all stakeholders to do is to be realistic and minimize predictions that are not based on facts.

On the other hand, Colman (2010) carried out a study in which he wanted to discover the network of actors in Botswana's power generation. The paper made use of literature review and 34 interviews focusing on clean energy transitions in Botswana and the roles of International and Southern African actors and decision-makers and key stakeholder groups and individuals within Botswana. Colman (2010)'s main argument was that, while Botswana should learn from other countries; care should be taken to compare like with like. This is because Botswana could run the danger of comparing their energy sector with that of developed countries; yet developed countries have privatized power companies and in Botswana, the government still owns and runs the power corporation. The level of efficiency and conceptualization differ. Hence, such comparison may not give accurate information for decision-making.

Karekezi \& Kithyoma (2001) carried out a study of rural energy sources in Sub-Saharan Africa. They reviewed emerging trends in the rural energy sector of sub-Saharan Africa and discussed the limitations of overreliance on solar PV. They suggested possible options that could have greater impact on rural clean energy development. Their findings were that most rural households in the region would likely keep using biomass fuels as the dominant fuel of choice. Solar thermal, wind pumps, micro/pico hydropower and cleaner fuels such as kerosene and LPG, have not received adequate attention from policymakers. These alternative energy options could significantly improve the performance of rural small and micro-enterprises. This article argues that rural energy policies that emphasize a broader range of renewable energy sources that target income-generating activities are likely to yield greater benefits to the rural poor than the current policies that rely on the solar PV option.

Thus, it is clear that wishful thinking will not help Botswana with clean energy. Rather, policymakers should map a way forward.

\subsection{What solutions can be put in place for Botswana to harness clean energy, particularly solar energy?}

4.1 Use of a conceptual model

The country could use the conceptual model made by the authors of this paper (Figure 1). 


\subsection{Benchmarking with Australia}

Australia is like Botswana in that a vast part of the country is a desert, just like Botswana. This means that both countries receive lots of solar radiation almost all-year-round. Australia's successful implementation of renewable energy, especially solar projects, in recent years could give Botswana insights on the way forward. Australia's success in this regard is demonstrated by the following statement, "More than 1.4 million solar power systems had been installed in Australia at the end of 2014, along with more than 900,000 solar hot water systems" (Clean Energy Council, 2014: 10).

Clean Energy Council (2014: 3) states that in Australia, household solar fared better than the large-scale sector in 2013. Increased consumer engagement and awareness about electricity prices and the benefits of solar technology meant more than 230,000 households and businesses installed either solar power or solar hot water. In terms of business, "More than 15,000 businesses have now installed a solar power system, collectively saving more than $\$ 64$ (Australian) million on their power bills every year" (Clean Energy Council, 2014: 4). This means that businesses in Australia are taking advantage of renewable energy sources to run their operations (Wong \& Cronin, 2019). Botswana enterprises that have suffered from power cuts could follow suit.

The Australian Renewable Energy Agency (ARENA) plays a major role in supporting renewable energy projects (Wright \& Hearps, 2011). In 2014 alone, Australian household and commercial solar $<100 \mathrm{~kW}$ stood at $4834 \mathrm{GWh}$, powering an equivalent of 680,900 households during the year 2014; while large-scale solar was at $118 \mathrm{GWh}$, powering an equivalent of 16,700 households during the year 2014 (Wong \& Cronin, 2019; Clean Energy Council, 2014: 7; Wright \& Hearps, 2011).

While the Australian government's actions are commendable, however, Wood \& Blowers (2015: 4) argue on the contrary, "About 1.4 million Australian homes have installed solar panels on their roofs since 2001. It is the largest take-up of photovoltaic (PV) solar systems of any country. These homeowners wanted to save money, depend less on the electricity grid, and play their part in tackling climate change. But lavish government subsidies plus the structure of electricity network tariffs means that the cost of solar PV take-up has outweighed the benefits by almost $\$ 10$ billion." Therefore, it follows that, while the Australian government had a good initiative; they spoiled the plan by over-subsidizing renewable energy projects. This serves as a warning to other countries such as Botswana so that when they implement such projects, they should let most of the costs to be borne by the consumers rather than by the government.

On the other hand, Magazzino (2017) carried out a study which investigated the stationary properties of electric power consumption in 18 
countries in the Middle East and North Africa (MENA) by using yearly data over the period 1971-2013. The findings were that the 'second generation 'panel unit root tests reveal mixed results. It was concluded that the choice of the deterministic component (constant vs. constant and trend) determine the results. Thus, it can be concluded that there are various factors that determine the results.

\subsection{Conclusion}

This study sought to find out Botswana's potential to power the country using solar energy projects. The empirical evidence has shown that solar energy is one of the best ways for Botswana to provide clean energy to the nation. However, there are challenges that come with solar energy implementation. For instance, it is expensive at first to implement the projects. But once the projects start running, in the long run; Botswana will benefit by stopping the importation of electricity, stopping power cuts and possibly exporting the solar power; thus, empowering local enterprises, earning foreign currency and boosting economic development. As the Botswana government leads the solar project, caution should be taken to avoid extravagant subsidies that could 'sink' the country's money.

\subsection{Recommendations}

It is recommended that the Botswana government should put together policies, regulations, and frameworks that support the use of solar energy as a major power generation strategy for the country. The conceptual model proposed by the authors of this paper as shown in Figure 1 could be helpful to decision-makers.

There is also needed to benchmark with other countries such as Australia that have experience in solar projects.

However, for ultimate success, the government should first privatize the Botswana Power Corporation to increase efficiency in project management.

Apart from domestic solar power, the government, with help of the private sector, should spearhead a major commercial solar project(s) that can supply most the country's power needs and export power.

The Australian Renewable Energy Agency (ARENA) plays a major role in supporting renewable energy projects. Botswana should form a renewable energy agency that will spearhead the solar power agenda. Care should, however, be taken by the government so that it will not repeat the Australian government error of over-subsidizing renewable energy projects thereby resulting in losses. 


\subsection{Study limitations and suggestions for further studies}

Firstly, the study is limited by use of the literature review methodology instead of field study. Secondly, there is an acute shortage of literature on solar energy in Botswana. Therefore, the researcher had to rely more on international sources, of which there are few peer-reviewed journal articles on the subject.

It is suggested that a field study should be done in Botswana to find out two things. Firstly, how ready is the nation to use solar energy as an alternative to regular electric power? Secondly, how ready is the government to come up with policies, regulations, and frameworks that support a major solar generation project?

\section{References:}

1. AfDB. (2009). Botswana: Morupule B. Power Project. Retrieved on $29^{\text {th }} \quad$ June 2016, from http://www.afdb.org/fileadmin/uploads/afdb/Documents/Environm ental-and-

SocialAssessments/ESIA\%20Ex\%20Summary\%20Morupule\%20B \%20Final-22\%20june09pdf

2. Baek, Y. J., Jung, T. Y., \& Kang, S. J. (2019). Low carbon scenarios and policies for the power sector in Botswana. Climate policy, 19(2), 219-230.

3. BIDPA. (2012). Coal Exports and the Diversification of Botswana's Economy. BIDPA Publication Series. Retrieved on $29^{\text {th }}$ April 2016, from https://www.africaportal.org/dspace/articles/coal-exportsand-diversification-botswanas-economy

4. BITC. (2016). Energy. Retrieved on $27^{\text {th }}$ April 2016, from https:www.bitc.co.bw/sector/energy

5. BITRI. (2018). BITRI On Second Phase of Renewable Energy. Retrieved on $14^{\text {th }} \quad$ August 2016, from https://www.mmegi.bw/index.php?aid=76712\&dir=2018/july/23

6. Bloomberg. (2014). Botswana Relies on Electricity Imports as Biggest Plant Fails. Retrieved on $29^{\text {th }}$ April 2016, from http://www.bloomberg.com/news/articles/2014-10-15/botswanarelies-on-electricity-imports-as-biggest-plant-fails

7. Boidus. (2014). How solar can power Botswana. Retrieved on $27^{\text {th }}$ April 2016, from http://boidus.co.bw/blog/?p=4261

8. Botswana Investors' Handbook. (2014). About Botswana. Retrieved on $29^{\text {th }} \quad$ April 2016, from https://www.sadc.int/files/1214/2358/3705/Botswana_Investors_H andbook.pdf 
9. Cavallaro, F., Zavadskas, E. K., Streimikiene, D., \& Mardani, A. (2019). Assessment of concentrated solar power (CSP) technologies based on a modified intuitionistic fuzzy topsis and trigonometric entropy weights. Technological Forecasting and Social Change, 140, 258-270.

10. Clean Energy Council. (2014). Clean Energy Australia Report 2014. Retrieved on $29^{\text {th }} \quad$ April 2016 , from https://www.cleanenergycouncil.org.au/.../reports/.../Clea...

11. Colman, T. (2010). The Governance of Clean Energy Development: A Case Study of Botswana and its Stakeholders. GCD Working Paper 006, June 2010

12. Department of Energy. (n.d.) 2-3-Compete-Conference - LusakaWright-Botswana, Retrieved on $28^{\text {th }}$ April 2016, from https://www.compete-bioafrica.net/events/events2/zambia/session2/ 2-3-Compete-Conference-Lusaka-Wright-Botswana

13. Islam, M. T., Huda, N., Abdullah, A. B., \& Saidur, R. (2018). A comprehensive review of state-of-the-art concentrating solar power (CSP) technologies: current status and research trends. Renewable and Sustainable Energy Reviews, 91, 987-1018.

14. Jacobs, T.M., (2018). A political risk analysis of Botswana (Doctoral dissertation, University of the Free State).

15. Karekezi, S. and Kithyoma, W. (2001). Renewable Energy Strategies for Rural Africa: Is a PV-led Renewable Energy Strategy the Right Approach for Providing Modern Energy to the Rural Poor of Sub-Saharan Africa? Retrieved on 29 ${ }^{\text {th }}$ April 2016, from http://solarenergypal.com/solar-energy-for-rural-africa/

16. Magazzino, C. (2017). Stationarity of electricity series in MENA countries. The Electricity Journal, 30(10), 16-22.

17. Maslamani, T. M., Omer, A. I., \& Majid, M. A. (2014). Development of solar thermoelectric generator. European Scientific Journal, 10(9).

18. Mensah, J.T., (2018). Jobs! electricity shortages and unemployment in Africa. The World Bank.

19. Mphinyane, W. N., Akanyang, L. K., Mulale, K., Van Deventer, F., Magole, L., Perkins, J. S., .. \& Chanda, R. (2018). Firewood Utilisation and Its Implication on Trees around Mopipi Village in Boteti Sub-District of Botswana. Asian Journal of Environment \& Ecology, 1-10.

20. Nkemelang, T., New, M., \& Zaroug, M. (2018). Temperature and precipitation extremes under current, $1.5 \mathrm{C}$ and $2.0 \mathrm{C}$ global warming above pre-industrial levels over Botswana, and 
implications for climate change vulnerability. Environmental Research Letters, 13(6), 065016.

21. Ofetotse, E. L. and Essah, E. A. (2012). Energy overview of Botswana: generation and consumption. In: WABER Conference 2012, 24-27 July 2012, Abuja, Nigeria, pp. 1011-1021. Retrieved on $29^{\text {th }}$ April 2016, from http://centaur.reading.ac.uk/28847/

22. Okonkwo, G.N. and Nwokoye, A.O.C. (2014) European Scientific Journal May 2014 edition vol.10, No.15 ISSN: 1857 - 7881 (Print) e - ISSN 1857- 7431

23. Pollmann, O., Podruzsik, S., \& van Rensburg, L. (2019). Risks and Opportunities of Sustainable Biomass and Biogas Production for the African Market. In Human and Environmental Security in the Era of Global Risks (pp. 277-289). Springer, Cham.

24. Prasad, J. and Samikannu, R., (2018). Barriers to implementation of smart grids and virtual power plant in sub-Saharan region-focus Botswana. Energy Reports, 4, pp.119-128.

25. Republic of Botswana. (2014). STEAG Maintains Morupule B. Plant. Retrieved on $29^{\text {th }}$ April 2016, from http://www.gov.bw/en/News/STEAG-maintains-Morupule-B/

26. SADOCC. (2014). STEAG Maintains Morupule B. Retrieved on $29^{\text {th }}$ April 2016, from http://www.sadocc.at/news/2014/2014001.shtml

27. Salahuddin, M., Ali, M. I., Vink, N., \& Gow, J. (2019). The effects of urbanization and globalization on CO 2 emissions: evidence from the Sub-Saharan Africa (SSA) countries. Environmental Science and Pollution Research, 26(3), 2699-2709.

28. Spear, D. D., Haimbili, E., Baudoin, M. A. D., Hegga, S. D., Zaroug, M. D., Okeyo, A., \& Angula, M. (2018). Vulnerability and adaptation to climate change in semi-arid areas in Southern Africa.

29. Streatfeild, J.E., 2018. Electricity Investment in Sub-Saharan Africa: A Historical Overview and a Way Forward. J. Int'l Com. \& Econ., p.1.

30. Sunday Standard. (2018). Botswana urged to make use of its solar resource. Retrieved on $14^{\mathrm{TH}}$ August 2019, from https://www.sundaystandard.info/botswana-urged-make-use-itssolar-resource

31. Tlhalerwa, K., \& Mulalu, M. (2019). Assessment of the concentrated solar power potential in Botswana. Renewable and Sustainable Energy Reviews, 109, 294-306.

32. Tola, M. (2015). Applying Modern Portfolio Theory to Plant Electricity Planning in Albania. European Scientific Journal April 
2015 edition vol.11, No.10 ISSN: 1857 - 7881 (Print) e - ISSN 18577431

33. UNDP. (2012). Energy Policy Brief Reflecting on the Challenges of Attaining a Green Economy for Botswana. Retrieved on $29^{\text {th }}$ April 2016, from https://sustainabledevelopment.un.org/content/documents/1009Nati onal\%20Report\%20(Energy)\%20-\%20Botswana.pdf

34. UNEP RISO CENTRE. (2012). CDM Investor Guide for Botswana. Retrieved on $29^{\text {th }}$ April 2016, from https://botswana.acpcd4cdm.org/media/358960/cdm-investor-guide_botswana.pdf

35. Vezzoli, C., Ceschin, F., Osanjo, L., M'Rithaa, M.K., Moalosi, R., Nakazibwe, V. and Diehl, J.C., (2018). Designing Sustainable Energy for All. Sustainable Product-Service System Design Applied to Distributed Renewable Energy (pp. 1-208). Springer.

36. Wong, P. S., \& Cronin, L. (2019, February). Drivers and Anticipated Outcomes of Solar Photovoltaic Projects-The Construction Practitioners' Perspectives. In IOP Conference Series: Materials Science and Engineering (Vol. 471, No. 11, p. 112006). IOP Publishing.

37. Wood, T. and Blowers, D. (2015). How Australia can finally get solar power right. Grattan Institute Report No. 2015-2, May 2015

38. World Bank. (2012). The Global Partnership for Wealth Accounting and Valuation of Ecosystem Services (WAVES) Report of the Botswana Preparation Phase. Retrieved on $29^{\text {th }}$ April 2016, from https://www.wavespartnership.org/sites/waves/files/documents/Fin al_WAVES_Botswana_Scoping_report_26.5.12.pdf

39. Wright, M. \& Hearps, P. (2011). Australian Sustainable Energy Zero Carbon Australia Stationary Energy Plan. Retrieved on $29^{\text {th }}$ April 2016, from https://www.bze.org.au/zero-carbon-australiastationary-energy-plan-available-now-d 